\title{
Influence of Green Initiatives on Environmental, Economic and Operational Outcomes: The Case of the Brazilian Packaging Supply Chain
}

\author{
Antonio C. S. Tavares ${ }^{1}$, Rosangela M. Vanalle ${ }^{1, *(D)}$ and João A. Camarotto ${ }^{2}$ \\ 1 Industrial Engineering Post Graduation Program, Universidade Nove de Julho (UNINOVE), CEP 05001-100 \\ São Paulo, SP, Brazil; acstavares@gmail.com \\ 2 Production Engineering Department, Universidade Federal de São Carlos (UFSCar), \\ CEP 13565-905 São Carlos, SP, Brazil; camarotto@dep.ufscar.br \\ * Correspondence: rvanalle@uni9.pro.br or rvanalle@terra.com.br
}

Received: 4 December 2018; Accepted: 9 January 2019; Published: 15 January 2019

\begin{abstract}
The adoption of green initiatives in supply chains is fundamental in the relationship among companies that have the obligation to assume the principles of environmental management. Packages take part in this scenario and they are fundamental in guaranteeing the quality of the products and their commercialization, bringing about the concern with their final destination and impacts caused to the environment. The aim of this research was to verify if the adoption of green initiatives in the packaging supply chain affects the environmental, economic and operational outcomes of companies participating in this chain, according to the perception of professionals who work in these companies. The study was conducted by means of a survey directed to professionals of various hierarchical levels working in Brazilian industries of the packaging supply chain. It is a quantitative study, and responses were analyzed through statistical techniques. The results have pointed out that only the environmental outcomes of companies in this supply chain were influenced by the adoption of green initiatives.
\end{abstract}

Keywords: green supply chain; packaging; green packaging; green initiatives; environmental outcomes; economic outcomes and operational outcomes

\section{Introduction}

Stimulated by marketing strategies and capitalism, the world's exponential growth of industrial production is aimed at meeting market demands, bringing serious challenges to avoid impacts to the environment and quality of life of future generations. Thus, it is necessary to rethink the consumption patterns of these resources, seeking sustainable consumption and prioritizing the use of renewable and less polluting sources of energy, as well as minimizing the consequences of accidents, natural or not, that may damage the world's capacity to supply the society demands. In addition, it is essential to reduce the generation of waste from economic activities, seeking new forms of use through either reuse or recycling [1].

In this context, the management of supply chain and operations has evolved from a model concerned only with operational and economic aspects to a model that also takes into account the social and environmental aspects of today's organizations [2].

Environmental issues are increasingly present in the daily life of stakeholders, and companies have been pressured to present sustainable management of their economic, social and environmental structures. In order to achieve environmental suitability, companies have adopted the green supply chain management (GSCM), which practice has expanded in several countries [3]. 
GSCM is defined as the integration of the environment with the supply chain management, including product design, researched and selected material, processes, delivery of the final product, as well as its management after the end of its life cycle [4].

GSCM assumes that companies act with interconnections from raw material suppliers to final consumers, constituting the so-called supply chains [5] involving three focuses: Environment, strategy and logistics. This approach seeks to locate competitive advantages based on better integration with the supply network, greater acceptance of ecologically correct products and cost reduction [6].

It should be highlighted that this concept also aims to encourage common sense in business and increased profitability [4].

Packaging participates in this scenario, which is a wrapping material or container that stores the product individually or temporarily groups units, whose main function is to protect and extend shelf life, enabling its identification, distribution and consumption [7]. Its main objective is to protect the product, but over time, it has assumed new functions, such as transmitting information, conquering the consumer, leveraging promotional actions, exposing, selling and optimizing logistics [8].

Although innovation is present in packaging development, production and use, most of the time, it is focused on the marketing or functional aspects of products. The few industries that choose to develop packaging with green attributes generally direct their efforts to the use of recycled materials, driven by marketing strategies, not giving due importance to sustainable raw materials with short degradation time [8]. Environmental management in the supply chain must also be present in a packaging project, since the final packaging is the result of the action of a complex productive chain, which after use is converted into an important component of urban waste, appearing with great visibility, due to its defined form and brands [9].

The achievement of environmental, operational and economic outcomes, influenced by the adoption of green practices in the supply chain, has been widely studied, but results are not conclusive [10]. There is therefore a need to include more developing countries in GSCM research [6].

According to Reference [11], researches published in Brazilian journals on GSCM are still predominantly theoretical, focusing on bibliometric research. Therefore, there are opportunities for conducting national or international empirical studies focusing on the Brazilian context, mainly because the discussion of how to adopt GSCM practices is still a little discussed theme.

The packaging industry traded around the world in 2015 more than US $\$ 500$ billion, reflecting between $1 \%$ and $2.5 \%$ of the GDP of each country. In Brazil, $\mathrm{R} \$ 47$ billion were traded in 2016, with the creation of more than 200 thousand formal and direct jobs [7].

Packaging is the silent seller of a product that competes in supermarkets with an average of another 30 thousand items [7]. Therefore, the association of packaging industries should encourage industries to manufacture products with environmental awareness to meet society demands.

Empirical evidence found in a literature review suggests that the adoption of Green initiatives in the supply chain improves the results in companies, as shown in Table 1 [10].

Table 1. Bibliographic references to influence the adoption of green initiatives.

\begin{tabular}{lll}
\hline Environmental Outcomes & $\begin{array}{l}\text { Compliance with environmental standards, Reduction in pollutant } \\
\text { emissions, Reduction in resource consumption and Reduction in the }\end{array}$ & {$[12,13]$} \\
Ese of hazardous materials. & $\begin{array}{l}\text { Increase in profit, Increase in Sales Volume, Increase in market share. } \\
\text { Eeduction of the Productive Resources consumption, Improvement }\end{array}$ & {$[12,13]$} \\
Operational Outcomes & $\begin{array}{l}\text { in product quality and Improvement in meeting deadlines and } \\
\text { flexibility of the production system. }\end{array}$ & {$[12,13]$} \\
\hline
\end{tabular}

There are five basic green initiative categories in the supply chain described in the literature: Eco-design, green purchasing, supplier environmental collaboration, customer environmental collaboration and reverse logistics. In real life, only some of these initiatives are widely adopted, while 
others are not. For this reason, in this research, only three initiatives were studied: Green purchasing, eco-design and reverse logistics [10].

The relationship among variables studied is presented in Figure 1. This is the basis for the formulation of hypotheses. Hypotheses in which the adoption of green initiatives in the supply chain will influence environmental, economic and operational outcomes are proposed [10].

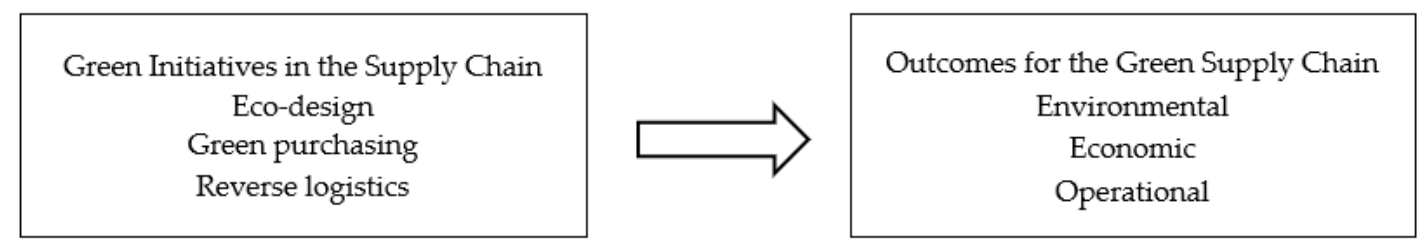

Figure 1. Relationship among variables investigated in the research.

Green initiatives in the supply chain are expected to produce better environmental performance inside and outside the organization. Internally, such initiatives can have a significant impact on reducing the consumption of hazardous materials and the production of waste, affecting overall working conditions. Externally, these initiatives should generate positive impacts on the environment, by reducing pollutant emissions and reducing waste of natural resources. Many studies have already indicated that there is a positive relationship between the level of adoption of green initiatives in the supply chain and the achievement of environmental outcomes [10,14]. Therefore, it is reasonable to propose the following hypotheses:

Hypothesis 1a. The adoption of the green purchasinginitiative influences the environmental outcome of the company.

Hypothesis $1 \mathbf{b}$. The adoption of the eco-designinitiative influences the environmental outcome of the company.

Hypothesis 1c. The adoption of the reverse logisticsinitiative influences the environmental outcome of the company.

In a more traditional view of the impact of green initiatives on the economic performance of companies, investments in the adoption of these initiatives are often associated with low return to shareholders [15]. Many scholars; however, point out that the adoption of green initiatives makes a lot of sense in the business world and some point out that it is a business opportunity $[16,17]$ and [18]. In addition, some authors believe that competitive strategies based on costs, differentiation or performance in niche markets can be dispensed based on environmental concerns [19]. Green eco-design initiatives through the substitution of materials or reduction in the use of materials contribute to meeting environmental objectives and also promote to reducing manufacturing costs, logistics costs and business opportunities in more restrictive markets from the environmental point of view. Some authors also found a positive relationship between the adoption of green purchasing initiatives and economic performance [10]. Based on the above, the following hypotheses can be proposed:

Hypothesis 2a. The adoption of green purchasinginitiatives influences the Economic outcome of the company.

Hypothesis $\mathbf{2 b}$. The adoption of eco-designinitiatives influences the influences the Economic outcome of the company.

Hypothesis 2c. The adoption of reverse logisticsinitiatives influences the Economic outcome of the company.

Operational performance includes cost reduction, improvements in product quality, improvements in logistics and flexibility of the production process [20]. However, other studies have discussed the 
feasibility of cost reduction through the adoption of green initiatives in the supply chain and argue that the adoption of these initiatives increases costs instead of reducing them $[15,21]$. It is reasonable to propose in this study the following hypotheses:

Hypothesis 3a. The adoption of green purchasinginitiatives influences the operational outcome of the company.

Hypothesis $3 \mathbf{b}$. The adoption of eco-designinitiatives influences the operational outcome of the company.

Hypothesis 3c. The adoption of reverse logisticsinitiatives influences the operational outcome of the company.

Thus, the research gap of this study lies on the fact that there are no studies showing the relationship between the adoption of green initiatives in the supply chain and the improvement in environmental, economic and operational outcomes. So, this study proposes the following research question:

Can the environmental, operational and economic outcome of companies included in the Brazilian packaging supply chain be influenced by the adoption of green practices?

The responses to this question were obtained by conducting a survey with companies participating in the Brazilian packaging supply chain.

\section{Materials and Methods}

This work has Applied Research design, which will be developed in the field of activities of companies involved in the supply chain under study, with the objective of obtaining information about the hypotheses raised [21].

The approach of this research will be quantitative with a predetermined structure and correlational objective for each formulated hypothesis. For the convenience of the Institutional Support from ABRE-Brazilian Association of Packaging Companies, with access to a large number of associates, survey data were collected using sampling and analysis techniques and statistical inference [22]. The survey-type data collection was applied in a cross-sectional way with a one-time study objective [23].

Data collection was performed through a questionnaire sent to the respondent by web link in an electronic form hosted in the Google Forms. Web link was sent by Email or WhatsApp through a letter of referral signed by ABRE-Brazilian Association of Packaging Companies for contacts registered in its database and in the list of contacts of the Author of this research work.

Sampling was performed among companies participating in the Brazilian chain of the packaging supply chain. For a 95\% significance level, and association between expected Strong or Medium variables, from 17 to 44 questionnaires are required [24].

According to Reference [7], a web link was sent to professionals of 207 associated companies, approximately 1000 contacts.

Web links were also sent to 65 networking contacts-the Author's network contacts in the packaging supply chain.

The first approach resulted in 55 responses. Through telephone follow-up for response in the electronic form, additional 80 responses were obtained, totaling 135 responses. After validation selection, 11 responses were not validated, remaining 124 valid responses.

The number of valid and answered questionnaires exceeded the $95 \%$ significance level and expected Strong or Medium association among variables [24].

Pre-test was performed with a group of 10 contacts that work in companies belonging to the Brazilian packaging supply chain, and after receiving the responses by web link, the Authors contacted the 10 respondents again and part requested that the fields for personal identification should be included as optional; another contribution was the idea of inverting the fields with responses using the 5 -point Likert scale to avoid responses without validation criterion by the respondent. The other form items remained unchanged. 


\section{Study Variables}

Three aspects were measured in this research in accordance with all considerations presented:

(a) The characterization of the companies participating in the research;

(b) The degree of adoption of green initiatives under study: Green purchasing, eco-design and reverse logistics.

(c) Environmental, operational and economic outcomes.

The degree of adoption of green initiatives in the Brazilian packaging supply chain was evaluated by means of three questions in the survey data collection questionnaire used in this research. For the respondent's reference, green initiatives were conceptualized in the questionnaire and responses were given on a 5-point Likert scale as follows: "I Strongly Agree ... ", "I Agree ... ", "I do not agree or disagree ... ", "I Disagree ... " and "I Strongly disagree... ". The sequence of responses was randomly inverted among the three questions. The electronic form allowed the choice of only one response.

\section{Results}

\subsection{Characterization of Companies Participating in the Research}

The first characteristic researched was the segment of the company participating in the packaging supply chain.

This segmentation was proposed in accordance with the end-use purpose of the package. Respondents from companies participating in this survey could submit more than one response and had a free text field available. The 124 survey respondents indicated all the segments of companies that they represent, with 436 segments in total. The distribution of segments is shown in Table 2.

Table 2. Distribution of segments of surveyed companies.

\begin{tabular}{ccc}
\hline Segments & $\begin{array}{c}\text { Number of } \\
\text { Occurrences }\end{array}$ & \% of Each Segment \\
\hline Food & 110 & $25.2 \%$ \\
\hline Beverages & 101 & $23.2 \%$ \\
\hline Cosmetics & 107 & $24.5 \%$ \\
\hline Pharmaceuticals & 49 & $11.2 \%$ \\
\hline Personal Hygiene & 52 & $11.9 \%$ \\
\hline Others & 17 & $3.9 \%$ \\
\hline General Total & 436 & $100.0 \%$ \\
\hline
\end{tabular}

The positioning of surveyed companies in the supply chain was also researched. In this question, the respondent was asked to identify in which part of the supply chain the company is located in accordance to the positioning proposed in the [7] yearbook. The result is shown in Table 3.

Table 3. Positioning distribution in the supply chain of surveyed companies.

\begin{tabular}{ccc}
\hline Positioning in the Supply Chain & Number of Occurrences & \% of Each Positioning \\
\hline Packaging Manufacturers & 57 & $46.0 \%$ \\
\hline Company that uses packaging inputs & 40 & $32.3 \%$ \\
\hline Raw material supplier & 11 & $8.9 \%$ \\
\hline Raw material converter & 6 & $4.8 \%$ \\
\hline Others & 5 & $4.0 \%$ \\
\hline Packaging development & 3 & $2.4 \%$ \\
\hline Post-consumption packaging activities & 2 & $1.6 \%$ \\
\hline General Total & 124 & $100.0 \%$ \\
\hline
\end{tabular}


The company's time in the packaging supply chain was researched by dividing companies into two groups: Companies with up to 15 years of operation and companies with a more than 15 years of operation [10]. The result of the time in the packaging supply chain of surveyed companies is presented in Table 4.

Table 4. Time distribution in the packaging supply chain of surveyed companies.

\begin{tabular}{ll}
\hline Operation Time & $\begin{array}{l}\text { \% of Each } \\
\text { Response }\end{array}$ \\
\hline Up to 15 years & $85.37 \%$ \\
\hline Less than 15 years & $14.63 \%$ \\
\hline General Total & $100.00 \%$ \\
\hline
\end{tabular}

The company size classification according to the number of employees indicates that companies with up to 100 employees are considered small and those with more than 101 and up to 500 employees are considered medium-size companies. Industries with more than 500 employees are considered large [25]. The result of the size of companies participating in this survey is shown in Table 5.

Table 5. Number of direct employees in surveyed companies.

\begin{tabular}{ll}
\hline Number of Direct Employees & \% of Each Response \\
\hline Less than 100 employees & $41.13 \%$ \\
\hline From 101 to 250 employees & $25.81 \%$ \\
\hline From 251 to 500 employees & $13.71 \%$ \\
\hline More than 1000 employees & $13.71 \%$ \\
\hline From 501 to 1000 employees & $5.65 \%$ \\
\hline General Total & $100.00 \%$ \\
\hline
\end{tabular}

The number of direct suppliers of materials and inputs of companies was investigated by classifying companies into two groups: Companies with more than 10 direct suppliers and companies with less than 10 direct suppliers [10]. The result is shown in Table 6.

Table 6. Number of direct suppliers of surveyed companies.

\begin{tabular}{cc}
\hline Number of Suppliers & \% of Each Response \\
\hline More than 10 suppliers & $79.03 \%$ \\
\hline Less than 10 suppliers & $20.97 \%$ \\
\hline General Total & $100.00 \%$ \\
\hline
\end{tabular}

The most frequent time of the relationship between surveyed companies and their suppliers divided companies into two groups: Companies with more frequent relationship with their suppliers of up to five years and those with a relationship of more than five years [10]. The result ofthis item is shown in Table 7. 
Table 7. Distribution of the most frequent time of the relationship between surveyed companies and their suppliers.

\begin{tabular}{lc}
\hline \multicolumn{1}{c}{ Most Frequent Duration of the Relationship with Suppliers } & \% of Each Response \\
\hline More than 5 years & $82.30 \%$ \\
\hline Up to 5 years & $17.70 \%$ \\
\hline General Total & $100.00 \%$ \\
\hline
\end{tabular}

The source of materials and inputs for companies was researched in an attempt to identify if the source of materials and inputs is the global market, the domestic market or Mercosur. The results are presented in Table 8.

Table 8. Distribution of the origin of materials and inputs for the surveyed companies.

\begin{tabular}{cc}
\hline Source of Materials and Inputs & \% of Each Response \\
\hline Regional market-Mercosur & $45.16 \%$ \\
\hline Domestic market & $29.84 \%$ \\
\hline Global Market & $25.00 \%$ \\
\hline General Total & $100.00 \%$ \\
\hline
\end{tabular}

The search for the source of the capital of companies was performed by asking the respondent to select one of the alternatives available in the form or the indication of another alternative through a free text field. A summary of the responses is presented in Table 9.

Table 9. Distribution of the source of capital of surveyed companies.

\begin{tabular}{cc}
\hline Source of Capital & \% of Each Response \\
\hline Brazil & $79.84 \%$ \\
\hline United States & $9.68 \%$ \\
\hline Europe & $7.26 \%$ \\
\hline Germany & $0.81 \%$ \\
\hline Chile & $0.81 \%$ \\
\hline Israel & $0.81 \%$ \\
\hline Japan & $0.81 \%$ \\
\hline General Total & $100.00 \%$ \\
\hline
\end{tabular}

It was also investigated which companies surveyed have adequate Environmental Management System-EMS-in compliance and certified according to ISO 14000 standard. The results are presented in Table 10.

Table 10. Distribution of surveyed companies with ISO 14000 Certification.

\begin{tabular}{cc}
\hline ISO 14000 Certification & \% of Each Response \\
\hline No & $67.74 \%$ \\
\hline Yes & $32.26 \%$ \\
\hline General Total & $100.00 \%$ \\
\hline
\end{tabular}

A summary of the hierarchical position of respondents is presented in Table 11. 
Table 11. Distribution of the hierarchical position of respondents in the surveyed companies.

\begin{tabular}{cc}
\hline Hierarchical Position of Respondents & \% of Each Response \\
\hline Technician & $62.10 \%$ \\
\hline Management & $27.42 \%$ \\
\hline Board of Directors & $7.26 \%$ \\
\hline Presidency & $3.23 \%$ \\
\hline Total & $100.00 \%$ \\
\hline
\end{tabular}

The characteristics of the companies participating in this research are summarized and presented in Table 12. The most frequent characteristic was considered, in which the frequency of occurrence exceeds the sum of frequencies of other characteristics. The criterion proposed in Reference [25] was considered in the size classification.

Table 12. Summary of the most frequent characteristics observed in the research.

\begin{tabular}{llc}
\hline \multicolumn{1}{c}{ Characteristic } & Most Frequent Characterizations & $\begin{array}{c}\text { Total Frequency of the Most } \\
\text { Frequent Classifications }\end{array}$ \\
\hline Business segment & Food, Beverages and Cosmetics & $72.90 \%$ \\
\hline Positioning in the supply chain & $\begin{array}{l}\text { Company that manufactures or } \\
\text { uses packaging }\end{array}$ & $78.30 \%$ \\
\hline Time in the supply Chain & More than 15 years & $85.30 \%$ \\
\hline Size by the number of employees & Small and Medium size & $80.65 \%$ \\
\hline Number of Direct Suppliers & More than 10 Direct Suppliers & $79.03 \%$ \\
\hline $\begin{array}{l}\text { Duration of the relationship with } \\
\text { Suppliers }\end{array}$ & More than 5 years & $82.30 \%$ \\
\hline $\begin{array}{l}\text { Source of materials and inputs } \\
\text { Origin of capital }\end{array}$ & Regional market-Mercosur and & $75.00 \%$ \\
\hline $\begin{array}{l}\text { ISO 14.000 standard } \\
\text { Hierarchical position of the }\end{array}$ & Brazil & $79.84 \%$ \\
\hline
\end{tabular}

\subsection{Adoption of Green Initiatives in the Brazilian Packaging Supply Chain}

Table 13 presents a summary of responses obtained to questions regarding the adoption of green initiatives in the practice of the company related with the supply chain.

Table 13. Proportion of responses regarding the adoption of green initiatives.

\begin{tabular}{cccc}
\hline Response & Green Purchasing & Eco-Design & Reverse Logistics \\
\hline I strongly agree & $12.1 \%$ & $12.9 \%$ & $13.7 \%$ \\
\hline I agree & $54.0 \%$ & $41.9 \%$ & $25.8 \%$ \\
\hline I do not agree or disagree & $28.2 \%$ & $36.3 \%$ & $47.6 \%$ \\
\hline I disagree & $4.8 \%$ & $8.1 \%$ & $9.7 \%$ \\
\hline I strongly disagree & $0.8 \%$ & $0.8 \%$ & $3.2 \%$ \\
\hline
\end{tabular}

Considering that the rejection to the adoption of green initiatives can be measured by "I disagree ..." " and "I strongly disagree ..." " responses, Table 14 shows the proportions and confidence intervals 
of respondents who strongly disagree or disagree that companies which they represent adopt green initiatives in their supply chains.

Table 14. Proportion of "I disagree ..." and "I strongly disagree ..." responses and confidence intervals for this proportion with $95 \%$ confidence.

\begin{tabular}{cccc}
\hline Response & Green Purchasing & Eco-Design & Reverse Logistics \\
\hline I Disagree + I Strongly Disagree & $5.6 \%$ & $8.9 \%$ & $12.9 \%$ \\
\hline Error-Confidence Interval-95\% conf. & $4.06 \%$ & $5.00 \%$ & $5.90 \%$ \\
\hline Minimum-Confidence interval & $1.58 \%$ & $3.87 \%$ & $7.00 \%$ \\
\hline Maximum-Confidence interval & $9.71 \%$ & $13.88 \%$ & $18.80 \%$ \\
\hline
\end{tabular}

Consequently, the proportion of respondents who do not disagree at any level in the adoption of green initiatives in the supply chain of companies is given by the difference in the total responses and is presented in Table 15.

Table 15. Proportion of "I strongly agree ... " and "I agree ... " and "I Do not disagree and do not agree..." " and confidence interval for this proportion with $95 \%$ confidence.

\begin{tabular}{cccc}
\hline Response & Green Purchasing & Eco-Design & Reverse Logistics \\
\hline $\begin{array}{c}\text { I Strongly agree + I agree + I Do not } \\
\text { disagree and do not agree }\end{array}$ & $94.4 \%$ & $91.1 \%$ & $87.1 \%$ \\
\hline Minimum-Confidence interval & $90.29 \%$ & $86.12 \%$ & $81.20 \%$ \\
\hline Maximum-Confidence interval & $98.42 \%$ & $96.13 \%$ & $93.00 \%$ \\
\hline
\end{tabular}

The results have shown that a large majority of respondents do not disagree that green initiatives are a practice in the companies they represent.

Data regarding the respondents' perception of the influence of green initiatives on environmental, economic and operational outcomes of companies will be summarized below. Data are presented as confidence intervals for the proportion of affirmative responses with a $95 \%$ confidence interval. An affirmative response means that the respondent perceives the influence of green initiatives on the outcomes of companies.

The first set of data measures the perception of the influence of green initiatives on the environmental outcomes of companies, presented in Table 16.

Table 16. Confidence intervals for the proportion of respondents who perceive the influence of green initiatives on the environmental outcomes of companies.

\begin{tabular}{cccc}
\hline Environmental Outcomes & Green Purchasing & Eco-Design & Reverse Logistics \\
\hline Minimum-Confidence interval-95\% conf & $61.2 \%$ & $43.6 \%$ & $45.3 \%$ \\
Maximum-Confidence interval-95\% & $77.5 \%$ & $61.2 \%$ & $62.8 \%$ \\
\hline
\end{tabular}

It is plausible to statistically state that at $95 \%$ confidence level, at least $61.2 \%$ of respondents perceive that "green purchasing" initiative influences the achievement of environmental outcomes; at least $43.6 \%$ of respondents perceived that the "eco-design" initiative influences the achievement of environmental outcomes and at least $45.3 \%$ of respondents perceived that the "reverse logistics" initiative influences the achievement of environmental outcomes.

The next set of data, presented in Table 17, measures the perception of the influence of green initiatives on the economic outcomes of companies. 
Table 17. Confidence intervals for the proportion of respondents who perceive the influence of green initiatives on the economic outcomes of companies.

\begin{tabular}{cccc}
\hline Economical Outcomes & Green Purchasing & Eco-Design & Reverse Logistics \\
\hline Minimum-Confidence interval-95\% conf. & $40.4 \%$ & $31.7 \%$ & $38.8 \%$ \\
\hline Maximum-Confidence interval-95\% conf. & $58.0 \%$ & $49.0 \%$ & $56.4 \%$ \\
\hline
\end{tabular}

The perception of the influence of green initiatives on the economic outcomes of companies was perceived by respondents in a smaller perception: Minimum of $40.4 \%$ for the "green purchasing" initiative, minimum of $31.7 \%$ for the "eco-design" initiative and minimum of $38.8 \%$ for the "reverse logistics" initiative.

Finally, the data set that measures the perception of the influence of green initiatives on the operational outcomes of companies is presented in Table 18.

Table 18. Confidence intervals for the proportion of respondents who perceive the influence of green initiatives on the operational outcomes of companies.

\begin{tabular}{cccc}
\hline Operational Outcomes & Green Purchasing & Eco-Design & Reverse Logistics \\
\hline Minimum-Confidence interval-95\% conf. & $47.7 \%$ & $30.1 \%$ & $24.8 \%$ \\
\hline Maximum-Confidence interval-95\% conf. & $65.2 \%$ & $47.3 \%$ & $41.3 \%$ \\
\hline
\end{tabular}

Operational outcomes are influenced by green initiatives for a smaller proportion of respondents: Minimum of $47.7 \%$ for the "green purchasing" initiative, minimum of $30.1 \%$ for the "eco-design" initiative and minimum of $24.8 \%$ for the "reverse logistics" initiative.

The statistical validation of hypotheses formulated throughout this work will be performed in the following chapter.

\section{Discussion}

To find evidence that the majority of respondents of this research perceive that green initiatives influence the outcomes of companies, the hypotheses developed in Section 2 were tested, and are related below:

Hypothesis 1a. The adoption of the green purchasinginitiative influences the environmental outcome of the company.

Hypothesis 1b. The adoption of the eco-designinitiative influences the environmental outcome of the company.

Hypothesis 1c. The adoption of the reverse logisticsinitiative influences the environmental outcome of the company.

Hypothesis 2a. The adoption of the green purchasinginitiative influences the economic outcome of the company.

Hypothesis $\mathbf{2 b}$. The adoption of the eco-designinitiative influences the economic outcome of the company.

Hypothesis 2c. The adoption of the reverse logisticsinitiative influences the economic outcome of the company.

Hypothesis 3a. The adoption of the green purchasinginitiative influences the operational outcome of the company.

Hypothesis $3 \mathbf{b}$. The adoption of the eco-designinitiative influences the operational outcome of the company. 
Hypothesis 3c. The adoption of the reverse logisticsinitiative influences the operational outcome of the company.

The hypothesis test proposed in this paper seeks evidence that the majority of respondents perceive that the company outcomes are influenced by green initiatives. In order to show that the majority of respondents have this perception, a unilateral hypothesis test was proposed, which is described by the following expression:

$\mathrm{H}_{0}: \mathrm{p}=0.50$-null hypothesis

$\mathrm{H}_{1}: \mathrm{p}>0.50$-alternative hypothesis

The aim of the test hypothesis is to reject the null hypothesis to statistically prove that the majority of respondents perceive the influence of green initiatives on the environmental, economic and operational outcomes of companies.

The null hypothesis is rejected if the result of the $t_{\text {test }}$ is greater than the $t_{\text {critical }}$ value for $5 \%$ significance level and (n-1) degrees of freedom [26], where $n$ is equal to 124. Referring to the Student $t$ distribution table, it could be concluded that the $t_{\text {critical }}$ value is equal to 1.66 .

The values of the $t_{\text {test }}$ statistics are presented in Table 19. These values are the basis for accepting or rejecting the null hypothesis, $\mathrm{H}_{0}$.

Table 19. Hypothesis test statistics.

\begin{tabular}{cccc}
\hline Test Statistics & Green Purchasing & Eco-Design & Reverse Logistics \\
\hline $\mathrm{t}$ test-Environmental Outcomes & 5.51 & 0.55 & 0.94 \\
\hline $\mathrm{t}$ test-Economic Outcomes & -0.18 & -1.97 & -0.53 \\
\hline $\mathrm{t}$ test-Operational Outcomes & 1.54 & -2.27 & -3.26 \\
\hline
\end{tabular}

Only in the case of the influence of green purchasing initiative on environmental outcomes, Hypothesis 1a, there was a rejection of the null hypothesis, which provided evidencethat the majority of respondents perceive the influence of the green purchasing initiative on the environmental outcomes of companies.

In all other cases, it was not possible to reject the null hypothesis and thus it was not possible to show that the majority of respondents perceive that green initiatives influence the outcomes of companies.

\section{Conclusions}

In Latin America and more specifically in Brazil, which is the geographical scope of this study, companies seek competitiveness to participate in the Global Market [27]. In the Global Market, the importance of green initiatives in the supply chain is mainly driven by the Environment deterioration, reduction in the availability of local raw materials and by the increasing levels of pollution [4]. The importance of green initiatives as promoters of competitiveness is perceived by respondents of this research, who widely do not disagree that at some level, green initiatives are adopted in the daily practices of companies.

Green purchasing brings to the supply chain the concern with the environmental performance of participants of this chain. The Purchasing function is at the beginning of the material flow and is in an advantageous position regarding the participants in the supply chain to make products and activities of the company to become green [28]. The regulatory role of the Purchasing function imposes to the supply chain the obligation to comply with the specifications of environmental aspects, which directly influences the environmental outcomes of the company and the supply chain, and most respondents in this survey perceive this influence. The acceptance of the alternative Hypothesis 1a: The adoption of the green purchasing initiative influences the environmental outcome of the company, evidences this result. 
At the same time, the incorporation of environmental aspects into the purchasing function can bring significant pressures and complications to the process, which can affect costs, lead time, supplier quality and flexibility [29]. According to this reference, it was not possible to show that the majority of respondents perceive that the green purchasing initiative influences the economic and operational outcomes of companies.

This research investigated the packaging supply chain and when it comes to packaging design, the most important aspects are: Content security, user ergonomics, supply chain sustainability, logistics optimization and Marketing/Communication [30]. Packaging design does not exist by itself, it is developed under briefing and specification of the company using the packaging and the interests of the important aspects in the development of packaging are conflicting regarding the purpose. Specific eco-design actions include the following concerns: Reduction or elimination of hazardous materials, reuse, recycling, remanufacturing, and increased resource efficiency [10]. According to the perception of the majority of respondents of this research, the eco-design initiative does not influence the environmental, economic and operational outcomes of companies.

In Brazil, reverse logistics is an obligation of Manufacturers, Importers, Distributors and Traders and an important part of this material flow refer to packaging. Reverse logistics in the packaging sector depends on technical and economic feasibility, and in areas where these aspects are solved. Reverse logistics has already become a reality. Respondents in this survey are packaging supply chain professionals and do not realize the influence of this initiative on environmental, economic, and operational outcomes. The low perception of the influence of reverse logistics on the outcomes of companies by respondents may come from the fact that most of the time, this initiative is operated by a company outside the supply chain [10].

Many studies have already indicated that there is a positive relationship between the level of adoption of green initiatives in the supply chain and the achievement of environmental outcomes $[10,14]$. In general, packaging supply chain Brazilian professionals do not realize the influence of green initiatives on environmental, economic and operational outcomes. The studies developed in References [12,20] also failed to show this relationship.

The response to the research question proposed in this paper is that in general, it was not possible to show that the perception of the majority of respondents is that green initiatives influence the environmental, economic and operational outcomes.

The main limitations of this study are related to the lack of face-to-face contact with respondents. The results obtained should guide the planning of new studies within the proposed theme.

Regarding opportunities for future works, studies with the same focus should be carried out in other industries, preferably in those that have specifications of their products. Another opportunity would be a comparative analysis between one or more characterization elements of surveyed companies.

Author Contributions: Data curation, Antonio Tavares and João A. Camarotto; Formal analysis, RosangelaVanalle; Investigation, Antonio Tavares; Methodology, João A. Camarotto; Writing-original draft, Antonio Tavares; Writing-review \& editing, RosangelaVanalle.

Funding: This research received no external funding.

Acknowledgments: The authors would like to thank UniversidadeNove de Julho (UNINOVE) and the surveyed companies for providing the support required for this research.

Conflicts of Interest: The authors declare no conflict of interest.

\section{References}

1. Rodrigues, S.C.; Peixoto, J.; Souza, X.L. Formação de cadeia verde de suprimentos a partir da gestão sustentável de resíduos industriais-Um exemplo no setor de reciclagem. Sistemas Gestão 2013, 8, 44-57. [CrossRef]

2. Fahimnia, B.; Sarkis, J.; Davarzani, H. Green Supply Chain Management: A review and bibliometric analysis. Int. J. Prod. Econ. 2015, 162, 101-114. [CrossRef] 
3. Sarkis, J.; Zhu, Q.; Lai, K.H. An organizational theoretic review of green supply chain management literature. Int. J. Prod. Econ. 2011, 130, 1-15. [CrossRef]

4. Srivastava, S.K. Green Supply-Chain Management: A state-of-the-art literature review. Int. J. Manag. Rev. 2007, 9, 53-80. [CrossRef]

5. Seuring, S.; Sarkis, J.; Müller, M.; Rao, P. Sustainability and supply chain management-An introduction to the special issue. J. Clean. Prod. 2008, 16, 1545-1551. [CrossRef]

6. Ferreira, M.A. Maturidade em gestão ambiental e adoção de práticas de Green Supply Chain Management: Proposta de um Framework Integrador à luz da análise de Múltiplos casos em Cadeias de alto Impacto Ambiental. Ph.D. Thesis, Faculdade de Economia, Administração e Contabilidade de Ribeirão Preto, Universidade de São Paulo, Ribeirão Preto, Brazil, 2014.

7. ABRE-Associação Brasileira de Embalagem. EMBALAGEM. 2017. Available online: http://www.abre.org. br/setor/apresentacao-do-setor/a-embalagem/ (accessed on 14 January 2018).

8. Landim, A.P. Sustainability concerning food packaging in Brazil. Polímeros 2016, 26. [CrossRef]

9. Silva, R.B. A ecoeficiência em relação aos atributos socioambientais comunicados nas embalagens dos produtos. Univ. Arquitetura Comunicação Soc. 2013, 10, 59-72.

10. Eltayeb, T.K.; Zailani, S.; Ramayah, T. Green supply chain initiatives among certified companies in Malaysia and environmental sustainability: Investigating the outcomes. Resour. Conserv. Recycl. 2011, 55, 495-506. [CrossRef]

11. Jabbour, A.B.; Azevedo, F.S.; Arantes, A.F. Greening the supply chain: Evidences of firms in Brazil. Gestão Produção 2013, 20, 953-962. [CrossRef]

12. Zhu, Q.; Sarkis, J.; Kee-Jung, L. Green supply chain management: Pressures, practices and performance within the Chinese automobile industry. J. Clean. Prod. 2007, 15, 1041-1052. [CrossRef]

13. Rao, P. Greening the supply chain: A new initiative in South East Asia. Int. J. Oper. Prod. Manag. 2002, 22, 632-655. [CrossRef]

14. Vanalle, R.M.; Salles, J.A. A Relação entre montadoras e fornecedores: Modelos teóricos e estudos de caso na indústria automobilística brasileira. Rev. Gestão Produção 2011, 18, 237-250. [CrossRef]

15. Walley, N.; Whitehead, B. It is not easy being green. Harv. Bus. Rev. 1994, 72, 46-51.

16. Paul, S. Enviromental technologies and competitive advantage. Strateg. Manag. J. 1995, 16, 183-200.

17. Porter, M.E.; Van Der Linde, C. Green and competitive: Ending the stalemate. Harv. Bus. Rev. 1995, 73, 120-134.

18. Heese, H.S.; Cattani, K.; Ferrer, G.; Gilland, W.; Roth, A.V. Competitive advantage through take-back of used products. Eur. J. Oper. Res. 2005, 164, 143-157. [CrossRef]

19. Hart, S.L. A natural-resource-based view of the firm. Acad. Manag. Rev. 1995, 20, 986-1014. [CrossRef]

20. Vachon, S.; Klassen, R.D. Supply chain management and enviromental technologies: The role of integration. Int. J. Prod. Res. 2007, 45, 410-423. [CrossRef]

21. Min, H.; Galle, W.P. Green purchasing practices of US firms. Int. J. Prod. Oper. Manag. 2001, 21, 1222-1238. [CrossRef]

22. Nakano, D. Métodos de pesquisa adotados na Engenharia de Produção e Gestão de Operações. In Metodologia de Pesquisa em Engenharia de Produção e Gestão de Operações, 2nd ed.; Miguel, P.A., Ed.; Elsevier: Amsterdam, The Netherlands, 2012.

23. Kumar, S.; Hong, Q.S.; Haggerty, L.N. A global supplier selection process for food packaging. J. Manuf. Technol. Manag. 2011, 22, 241-260. [CrossRef]

24. Forza, C. Survey research in operations management: A process-based perspective. Int. J. Oper. Prod. Manag. 2002, 22, 152-194. [CrossRef]

25. SEBRAE. Anuário do Trabalho na Micro e Pequena Empresa. 2013. Available online: http://www.sebrae.com. br/Sebrae/Portal\%20Sebrae/UFs/SP/Pesquisas/MPE_conceito_empregados.pdf (accessed on 20 December 2016).

26. Neyman, J.; Pearson, E. Sufficient Statistics and Uniformly Most Powerful Tests of Statistical Hypotheses, 1st ed.; University of California Press: Berkeley, CA, USA, 1936.

27. Ruiz-Torres, A.J.; Mahamoodi, F.; Ayala-Cruz, J. Supply Chain Management Research in Latin America: A review. Supply Chain Forum Int. J. 2012, 13, 20-36. [CrossRef]

28. Preuss, L. In dirty chains? Purchasing and greener manufacturing. J. Bus. Ethics 2001, 34, 345-359. [CrossRef] 
29. Handfield, R.B.; Melnyk, S.A.; Calantone, R.J.; Curkovic, S. Integrating enviromental concerns into the design process: The gap between theory and practice. IEEE Trans. Eng. Manag. 2001, 48, 189-208. [CrossRef]

30. Azzi, A. Packaging design: General Framework and Research Agenda. Packag. Technol. Sci. 2012, 25, 435-456. [CrossRef]

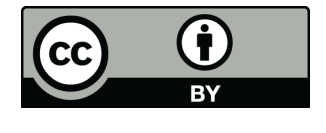

(C) 2019 by the authors. Licensee MDPI, Basel, Switzerland. This article is an open access article distributed under the terms and conditions of the Creative Commons Attribution (CC BY) license (http://creativecommons.org/licenses/by/4.0/). 